\title{
THE EFFECTS OF VOCABULARY MASTERY AND LOGICAL THINKING TOWARDS STUDENT'S LISTENING SKILL AT PRIVATE VOCATIONAL HIGH SCHOOLS IN EAST JAKARTA
}

\author{
Wita Wulandari \\ Program of Informatics Engineering, Faculty of Mathematics and Natural Sciences, \\ University of Indraprasta PGRI \\ Jalan Nangka No. 58C Tanjung Barat, Jagakarsa, Jakarta Selatan 12530 \\ witawullandari@gmail.com
}

\begin{abstract}
The aim of this research is to find out the effect of vocabulary mastery and logical thinking towards the students' listening skill. The research was conducted at SMK. The population in this research is 450 students of Grade XI, with 90 sample students. The method used in this research is a survey method. The data is obtained from the vocabulary test, logical thinking test and listening test. The hypothesis test showed that there are many significant effects of vocabulary mastery and logical thinking towards listening skill. That is proved by the value of Sig. $0,000<0,05$ and $F_{o}=19,049$. Based on the result of the research, it proves that students' vocabulary and logical thinking mastery give positive contribution towards the students' listening skill.
\end{abstract}

Key words: vocabulary mastery, logical thinking, listening skill

\begin{abstract}
ABSTRAK
Tujuan dari penelitian ini adalah untuk mengetahui adanya pengaruh penguasaan kosakata dan berpikir logis terhadap keterampilan mendengarkan siswa. Penelitian dilakukan di SMK. Populasi penelitian ini adalah 450 siswa kelas 11, dengan sampel 90 siswa. Metode yang digunakan dalam penelitian ini adalah metode survei. Data diperoleh dari ujian kosakata, ujian berpikir logis dan ujian mendengarkan. Uji hipotesa menunjukkan adanya pengaruh yang signifikan dari penguasaan kosakata dan berpikir logis terhadap keterampilan mendengarkan. Hal ini terbukti dari nilai Sig. 0,000 <0,05 and $F_{o}=19,049$. Berdasarkan hasil penelitian terbukti bahwa kosakata siswa dan penguasaan berpikir logis memberikan kontribusi positif terhadap keterampilan mendengarkan siswa.
\end{abstract}

Kata kunci: penguasaan kosakata, berpikir logis, keterampilan mendengarkan. 


\section{INTRODUCTION}

Human beings use language as a means of communication. By using language, they can express their experiences and ideas to others, both in spoken and written forms. In the learning process, one has to make interaction with another through communication. They communicate through language. Language is a form of communication between people. People use many reasons in their life. Language plays an important role in the society. It is impossible to communicate with others without language.

Someone who masters the first language in many occasions is also expected to master other languages. At the present time, English is the language most widely used in the world's society. Nevertheless, English is considered as an international language, formally or informally, in the parts of societies in many countries. Indonesia as one of developing countries needs to communicate or to interact by using English to conduct social relationship, commercial and educational activities. Realizing that English as an important tool of communication, the government has decided that English is used as the first foreign language and as one of the compulsory subjects in the elementary, junior, senior high school and universities.

By the end of the twentieth century, English was already well known on its way to become a genuine lingua franca, that is, a language used widely for communication between people who do not share the same first (or even second) language. Just as in the Middle Ages Latin became for a time a language of international communication at least in the Roman Empire, so English is now commonly used in the exchanges between, say, Japanese and Argentinean business people, or between
Singaporeans and their Vietnamese counterparts. English is also, of course, a mother tongue for many people in the world, though, as we shall see, such native speakers are increasingly outnumbered by people who have English as a second or third language and use it for international communication (Harmer, 2007).

Around the world, English is taught in a variety of situations. In many countries it first appears in the primarily curriculum, but many universities in those and other countries continue to find that their entrants are insufficiently competent in English use, even if, as Graddol (2006:122) points out that "Good English is an entry requirement for much tertiary education in a global market where English gives the user a competitive advantage".

English which is most widely used is one of the international languages, taken as a native language, as a second language, or a foreign language in almost all over countries in the world. English is a language used in all aspects of communication, sciences and technology. English is the system of sound and words used by human to express their ideas and feeling. Therefore, a language is a system of visual, auditory or tactical symbols of communication of the rules used to manipulate them. We can conclude that language is considered to be a system of communication with other people using sounds, symbols, and words in expressing meaning, idea or thought. This language can be used in many forms, primarily through oral and written communication as well as using express on through body language.

Language plays an important role in developing intellectual, social, and emotional of the students, and also it is the key to the success in learning of all fields of study. It is therefore, the 
curriculum of language at school is to prepare the students to achieve the competence in which the students are able to reflect their own experience and other people's experience, to express their opinions and emotions, and to understand variety of meaning. Language is expected to help the students know their own culture, to participate in the society by using the language. In Indonesia, English is considered as a first foreign language and becomes a compulsory subject from elementary to university as affirmed by The Department of Education and Cultural stated in English curriculum of Senior High School 2004 (2004:310) as the followings:

"That in the context of education, the function of English language is as a tool to communicate in order to access the information, to make interpersonal relationship, to exchange information and also to enjoy the art of language in English culture".

Competency Based Curriculum 2004-2009 tries to develop and achieve the communicative competence or discourse competence and has perspective that is comprehensive of the discourse. The students must be able to master the four skills: listening, reading, speaking, and writing. In addition, they should also master English components such as grammar, vocabulary, and pronunciation.

The ways we use language tend to be talked by teachers, in terms of four skills - reading, writing, speaking and listening. These are often divided into two types, receptive and productive skill. Receptive skill is a term used for reading and listening, skills where meaning is extracted from the discourse. Productive skill is the term for speaking and writing, skills where students actually have to produce language themselves. Of course, every day we listen to a variety of different things. How we listen and what we do when we listen depends on our purpose. Because it is something we do every day, listening seems simple. Yet, when one is listening in a second or foreign language, we can see more easily how complex listening really is.

Listening is only one facet of language development, like the skill of reading, listening is a receptive skill and can be accomplished at a higher rate of speed that can be speaking or composing, both of which require the human mechanism to 'do something' physical. Although usually taught last, therefore, listening soon overtakes other language skills, particularly that of speaking. Many students do not realize the importance of listening.

As teachers, we are hoped not only to transfer the knowledge but also to arouse the students' interest especially in listening because the students usually underestimate their listening skill. If you are teaching in the Private Senior High School, you will find the fact that many of students are careless of the listening subject. In class, we are faced to some students who are careless about listening subject and at the end of the lesson we are also going to find that their score is very low based on their careless. In listening, one component of English is vocabulary. Vocabulary also plays an important role, because the mastery of vocabulary will influence the understanding of phrases, sentences, and paragraphs. According to Nation and Newton (2001:114), "Learners would need at least $95 \%$ coverage of the running words in the input in order to gain reasonable comprehension and to have reasonable success at guessing from the context".

From the statement above, it means that the students also have to 
master vocabularies or words while they are listening to the text, stories, monologue or dialogues. In learning vocabulary, there are many words in the lexicon of a language. In senior high school, the vocabulary mastery is more or less 2500 words for non-language department. Besides, in most lesson's units, the number of new words is commonly very large and too much demanding for the learner who will naturally fail to retain them, most of the words will be forgotten during or soon after the lesson. Hence, vocabulary mastery will support the achievement of listening comprehension skill without neglecting the grammar.

In the other hand, if we look into it carefully, we are also going to find that there are some of the students who are very good in listening, they have more attention than the others, and they actually have a wide vocabulary in their mind and after they listen for the speaker of an audio, they have a very good logical thinking to answer some questions of the listening test as usually the audio of listening is taken from sources outside of our country, such as from British and American. Therefore, the students who have a basic of vocabulary mastery and logical thinking will have a good score. Based on the writer's experience in teaching listening comprehension at the University of Indraprasta PGRI, the writer is interested in finding out whether there is an effect between vocabulary mastery and logical thinking through listening skill at Private High School in East Jakarta.

\section{METHOD}

It is a fact that in the research, we have to use a method. The method that will be used in this research is Survey. This method, according to Sevilla, et al. (1993) pointed out the determination of information about variable, not about the information of individual. The application of this method performs through tested instrument to the students by using multiple choice test for the vocabulary mastery and logical thinking, and a listening comprehension test. So, the relationship design that is becoming the correlation in this research is as below:

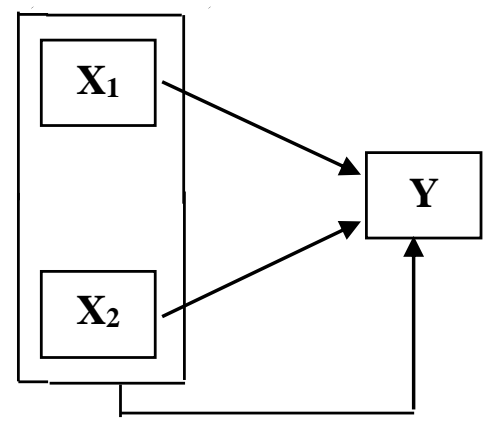

Diagram 1. Research Design

Description:

$\mathrm{X}_{1}$ : Vocabulary Mastery

$\mathrm{X}_{2}$ : Logical Thinking

$\mathrm{Y}$ : Listening Skill

\section{RESULTS AND DISCUSSION Normality Test Data}

The test requirements regression is good if the data research is normal.

Table 1 . Test Normality Data

\begin{tabular}{|l|l|l|l|l|}
\hline \multicolumn{5}{|c|}{ One-Sample Kolmogorov-Smirnov Test } \\
\hline \multicolumn{2}{|c|}{} & $\begin{array}{l}\text { Listening } \\
\text { Skill }\end{array}$ & $\begin{array}{l}\text { Vocabulary } \\
\text { Mastery }\end{array}$ & $\begin{array}{l}\text { Logical } \\
\text { Thinking }\end{array}$ \\
\hline $\mathrm{N}$ & 90 & 90 & 90 \\
\hline \multirow{2}{*}{$\begin{array}{l}\text { Normal } \\
\text { Parameters }\end{array}$} & Mean & 77.78 & 79.56 & 79.23 \\
\cline { 2 - 5 } & $\begin{array}{l}\text { Std. } \\
\text { Deviation }\end{array}$ & 9.502 & 9.791 & 9.365 \\
\hline \multirow{2}{*}{$\begin{array}{l}\text { Most } \\
\text { Extreme } \\
\text { Differences }\end{array}$} & Absolute & .110 & .129 & .088 \\
\cline { 2 - 5 } & Positive & .093 & .126 & .080 \\
\cline { 2 - 5 } & Negative & -.110 & -.129 & -.088 \\
\hline Kolmogorov-Smirnov Z & 1.041 & 1.226 & .837 \\
\hline
\end{tabular}




\begin{tabular}{|l|l|l|l|}
\hline Asymp. Sig. (2-tailed) & .229 & .099 & .486 \\
\hline a. Test distribution is Normal. \\
\hline b. Calculated from data. \\
\hline
\end{tabular}

heteroskedastisitas is if mistake or residual to observe do not have a constant variant. Condition of heteroskedastisitas often happens a cross section data, or data sample

From the above table, it can be seen that the test hypothesis distribution data analysis regression is normal distribution. All score of A symp is sig > 0,05 . The data distribution is normal.

\section{Test of Multikolinearitas}

Test of multikolinieritas purposes to test what model regression find correlation is perfect between variable of free (independent). Model regression which is good must not be happened in the correlation seems perfect among free variable. One of the ways to detection a multikolinieritas is we can see tolerance or varian inflation factor (VIF). If tolerance $<0,1$ or score VIF> 10 so happens multikolinearitas.

Table 2. Test of Multikolinearitas

\begin{tabular}{|c|c|c|c|}
\hline \multicolumn{4}{|c|}{ Coefficients $^{\mathbf{a}}$} \\
\hline \multirow{2}{*}{\multicolumn{2}{|c|}{ Model }} & \multicolumn{2}{|c|}{ Collinearity Statistics } \\
\hline & & Tolerance & VIF \\
\hline \multirow{3}{*}{1} & (Constant) & & \\
\hline & $\begin{array}{l}\text { Vocabulary } \\
\text { mastery }\end{array}$ & .806 & 1.241 \\
\hline & $\begin{array}{l}\text { Logical } \\
\text { thinking }\end{array}$ & .806 & 1.241 \\
\hline
\end{tabular}

The result test of multikolininearitas on table above, releases the value of Tolerance $0,806>$ 0,1 or variant inflation factor (VIF) 1,241 $<$ 10. So we conclude no multikolinearitas between vocabulary mastery and logical thinking in this analysis double regression.

2. Test of Heteroskedastisitas Definition of from some respondents. One of the methods to dictation have a heteroskedastisitas is to make scatter-plot between standardized Residual (ZRESID) and Standardized Predicted Value (Y topi). In this picture below, to show no change e until $\mathrm{Y}$ topi, so we conclude no have heteroskedastisitas to galat (error/residual).

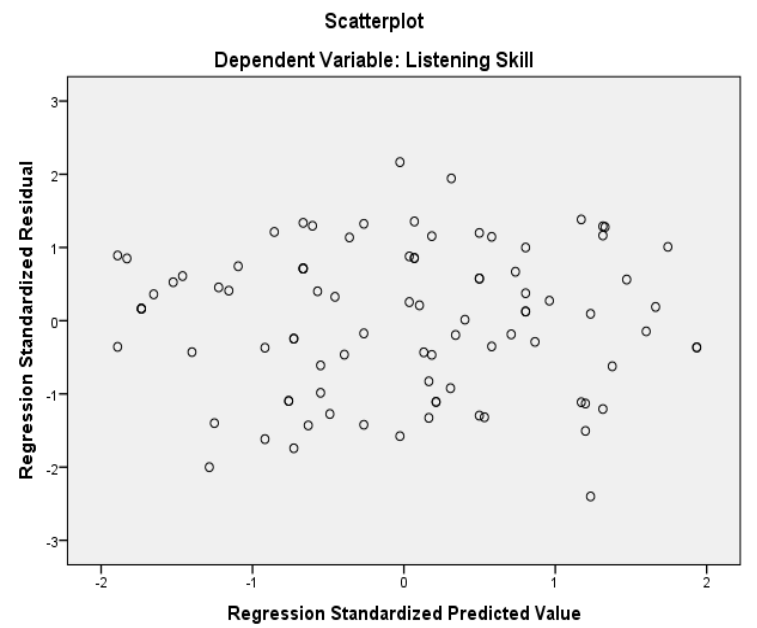

Figure 1. Scatterplot Test of Heteroskedastisitas

From the picture above, the findings show that the dot spreads randomly and there is not clear pattern, and spreads between 0 and Y. So, it can't happen heteroskedastisitas on regression model to predict listening skill variable according to vocabulary mastery and logical thinking.

The effect of vocabulary mastery (X1) and logical thinking (X2) towards student's listening skill(Y)

This hypothesis effect is:

$$
\begin{gathered}
H_{0}: \beta_{y 1}=\beta_{y 2}=0 \\
H_{1}: \beta_{y 1} \neq 0, \beta_{y 2} \neq 0
\end{gathered}
$$

means:

$\mathrm{H}_{0} \quad$ : there is no significant effect between vocabulary mastery 
$\left(\mathrm{X}_{1}\right)$ and logical thinking

$\left(\mathrm{X}_{2}\right)$ towards student's listening skill (Y)

$\mathrm{H}_{1}$ : there is significant effect between vocabulary mastery $\left(\mathrm{X}_{1}\right)$ and logical thinking $\left(\mathrm{X}_{2}\right)$ towards student's listening skill (Y)

From the table, we can see that the effect of double coefficient correlation of independent variable of vocabulary mastery and logical thinking towards student's listening skill. The value of Sig. $0,000<0,05$ and $F_{0}=19,049$.

While, Line regression double with $\hat{Y}=27,315+0,385 \mathrm{X} 1+0,250 \mathrm{X} 2$. The understanding that the increase of one score variable of vocabulary mastery and logical thinking gives contribution 0,385 by $\mathrm{X} 1$ and 0,250 by $\mathrm{X} 2$ towards the variable of listening skill. It explains that together the variable of vocabulary mastery and logical thinking gives contribution $30.5 \%$ towards variable listening skill.

The result research above concludes that vocabulary mastery and logical thinking together give a positive effect towards the increase of listening skill of students at Private High School in East Jakarta. Vocabulary mastery and logical thinking give a significant effect towards the increase of listening skill of students at Private High School in East Jakarta.

The students have to master vocabularies or words while they are listening to the text, stories, monologue or dialogues. In learning vocabulary, there are many words in the lexicon of a language. Vocabulary mastery will support the achievement of listening comprehension skill without neglecting the grammar. In the other hand, if we look into it carefully we are also going to find that there are some of the students who are very good in listening, they have more attention than the others, and they actually have a wide vocabulary in their mind and after they listen for the speaker of an audio they have a very good logical thinking to answer some questions of the listening test. The students who have a basic of vocabulary mastery and logical thinking will have a good score.

\section{CONCLUSION}

There are many significant effects of vocabulary mastery and logical thinking towards listening skill. That is proved by Sig. $0,000<0,05$ and $F_{o}=$ 19,049 . Vocabulary mastery and logical thinking gives contribution $30.5 \%$ towards variable listening skill.

There is a significant effect of vocabulary mastery towards listening skill. That is proved by the value of Sig. $0,000<0,05$ and $t_{o}=3,987$. Variabel vocabulary mastery gives contribution $20,09 \%$ improve listening skill.

There is a significant effect of logical thinking towards listening skill. That is proved by the value of Sig. $0,015<0,05$ and $t_{0}=2,475$. Variabel logical thinking gives contribution $10,36 \%$ improve listening skill.

\section{REFERENCES}

Departemen Pendidikan dan Kebudayaan. (2004). Kurikulum 2004 GBPP SMA. Jakarta.

Graddol, D. (2006). English Next. The British Council.

Harmer, J. (2007). How to Teach English. England: Pearson Education Inc.

Nation, I.S.P., \& Newton, J. (2009). Teaching ESL/EFL Listening and Speaking. New York: Routledge.

Sevilla, C. G., et. al. (1993). An Introduction to Research Methods Translator: Alimuddin 
Tижи. Jakarta: Universitas

Indonesia.

218 Scope: Journal of English Language Teaching, Vol.01 Issue 2, Mar 2017, 212-218 